\title{
Efficacy of Pinoxaden alone and in Combination with Metsulfuron-Methyl and Carfentrazone-Ethyl against Complex Weed Flora in Barley (Hordeum vulgare $\mathrm{L}$.)
}

\author{
Bhagat Singh $^{1}$, Mukesh Kumar ${ }^{1}$, A.K. Dhaka ${ }^{1}$ and R.A.S. Lamba ${ }^{2}$ \\ ${ }^{1}$ Department of Agronomy, College of Agriculture, CCS Haryana Agricultural University, \\ Hisar-125004 (Haryana), India \\ ${ }^{2}$ CCS Haryana Agricultural University, Regional Research Station, Bawal-123501, \\ Haryana, India \\ *Corresponding author
}

\section{Keywords \\ Barley, Hordeum vulgare $\mathrm{L}$., \\ Pinoxaden, \\ Weed control, Herbicides, Yield. \\ Article Info \\ Accepted: \\ 02 March 2017 \\ Available Online: \\ 10 April 2017}

\section{A B S T R A C T}

To find out the efficacy of Pinoxaden alone and in combination with Metsulfuron and Carfentrazone against complex weed flora in barley (Hordeum vulgare L.), an experiment was conducted at CCS Haryana Agricultural University, Hisar during rabi 2013-14. The experiment was arranged in randomized block design and was replicated thrice with eleven weed control treatments comprised of individual application of Pinoxaden @ 30, 40 and 50 $\mathrm{g} \mathrm{ha}{ }^{-1}$, tank mixture of Pinoxaden@40 $\mathrm{g} \mathrm{ha}^{-1}$ with Metsulfosulfuron@ $4 \mathrm{~g} \mathrm{ha}^{-1}$ and Carfentrazone @ $20 \mathrm{~g} \mathrm{ha}^{-1}$, Pinoxaden $f b$ Metsulfuron $\left(40+4 \mathrm{~g} \mathrm{ha}^{-1}\right)$, individual application of Isoproturon@1000 $\mathrm{g} \mathrm{ha}^{-1}$, tank mixture of Isoproturon@750 $\mathrm{g} \mathrm{ha} \mathrm{h}^{-1}$ with 2,4-D @ 500 $\mathrm{g} \mathrm{ha}{ }^{-1}$ and Metsulfuron@ $4 \mathrm{~g} \mathrm{ha}^{-1}$, weedy check and weed free. Result of the experiment revealed that Pinoxaden@50 $\mathrm{g} \mathrm{ha}^{-1}$ was very efficient against grassy weeds without any phytotoxic effect, but is ineffective against broad-leaf weeds. Tank mix application of Pinoxaden@40 $\mathrm{g} \mathrm{ha}^{-1}$ with broad-leaved herbicides i.e. Metsulfuron@ $4 \mathrm{~g} \mathrm{ha}^{-1}$ and Carfentrazone @20 $\mathrm{g} \mathrm{ha}^{-1}$ and Pinoxaden $f b$ Metsulfuron $\left(40+4 \mathrm{~g} \mathrm{ha}^{-1}\right)$ proved effective in controlling mixed weed flora and total dry weight of weeds at 60 and 90 days after sowing. Pinoxaden $f b$ Metsulfuron@ $@ 40+4 \mathrm{~g} \mathrm{ha}^{-1}$ produced significantly higher grain yield than individual application of different herbicides and weedy check but statistically at par with tank mixture of Pinoxaden@ @ $40 \mathrm{~g} \mathrm{ha}^{-1}$ with Metsulfuron@ $4 \mathrm{~g} \mathrm{ha}^{-1}$ and Carfentrazone @ $20 \mathrm{~g} \mathrm{ha}^{-1}$. Presence of weeds throughout the growing season brought about $24 \%$ reductions in grain yield as compared to weed free treatment. The increase in grain yield of barley due to application of Pinoxaden @ $40 \mathrm{~g} \mathrm{ha}^{-1} \mathrm{fb}$ Metsulfuron@ $9 \mathrm{~g} \mathrm{ha} \mathrm{g}^{-1}$ was $22.5 \%$ over weedy check. Increased grain yield in herbicide mixture of Pinoxaden @ $40 \mathrm{~g} \mathrm{ha}^{-1}$ with Metsulfuron@4 $\mathrm{g} \mathrm{ha}^{-1}$ and Carfentrazone @ $20 \mathrm{~g} \mathrm{ha}^{-1}$, Pinoxaden @ $40 \mathrm{~g} \mathrm{ha}^{-1} \mathrm{fb}$ by Metsulfuron@4g ha ${ }^{-1}$ could be ascribed to poor weed growth, weed dry matter and more number of grains earhead ${ }^{-1}$ and test weight when compared with alone application of herbicides and weedy check treatment. Higher weed control efficiency with lower weed index was recorded under Pinoxaden $f b$ Metsulfuron $\left(40+4 \mathrm{~g} \mathrm{ha}^{-1}\right)$ applied treatment. 


\section{Introduction}

Barley is considered fourth largest cereal crop of the world after wheat, rice and maize with a share of $7 \%$ of the global cereal production and third important cereal after rice and wheat in India (Pal et al., 2012). Irrigated barley with high fertilization usually suffers from crop weed competition. Weeds are the most underestimated crop pests in tropical agriculture and cause maximum loss in the yields of crops than other pests and diseases. Of the total annual loss of agricultural produce from various pests in India, weeds roughly account for $37 \%$, insects for $29 \%$, diseases for $22 \%$ and other pests for $12 \%$ (Yaduraju, 2006). The major weeds of barley crop are Phalaris minor, Anagallis arvensis, Avena fatua, Cirsium arvensis, Vicia sativa, Melilotus alba and indica, Chenopodium album, Chenopodium murale, Convolvulus arvensis, Rumex dentatus, Lathyrus aphaca, Euphorbia hirta, Polypogon monspeliensis and Avena ludoviciana (Singh and Punia, 2007). If the weeds are not controlled at the critical stages of crop, they may cause reduction in yield up to $66 \%$ (Kumar et al., 2011). They compete with crop plants for light, water and Nutrients. Weeds inflict huge nutrient and yield losses, suggesting adopt strong management strategies (Suresha et al., 2015). Isoproturon and 2,4-D were the only adopted herbicides recommended for grassy and broad leaf weed control in barley. Resistance has evolved in $P$. minor against isoproturon, which was the most commonly used herbicide earlier in wheat and barley (Chhokar and Malik, 2002). Due to resistance to isoproturon in Phalaris minor, this herbicide has limitations of use (Singh, 2007; Ram and Singh, 2009) and not all wheat herbicides are selective for barley (Singh and Punia, 2007).

Wheat herbicides (sulfosulfuron and mesosulfuron) used for control of Phalaris minor in wheat are not safe for barley (King,
2007). Pinoxaden, belonging to phenylpyrazolin group with acetyl-COAcarboxylase (ACCase) has inhibiting action (Hoffer et al., 2006). It is a selective grass killer with foliar action. Pinoxaden 40-60 g $\mathrm{ha}^{-1}$ is very effective against Avena ludoviciana and Phalaris minor without any phytotoxicity, but is ineffective against broadleaf weeds (Singh and Punia, 2007; Chhokar et al., 2008). Since grass killers don't control the broad-leaved weeds. Herbicide 2,4-D provides effective control of broad-leaf weeds in barley but 2,4-D if used with phenylpyrazolin group of herbicides antagonizes the effect of graminicides in wheat (Balyan et al., 1993). Alternative herbicides viz. sulfosulfuron, clodinafoppropargyl, and fenoxaprop-p-ethyl, which are effective against Phalaris minor are not safe to barley crop (Singh and Punia, 2007) where as no crop phytotoxicity was observed with Pinoxaden. Herbicides with differential selectivity can be applied sequentially but it involves application twice, resulting in enhanced cost. Therefore mixing two different herbicides and applying them simultaneously widens the spectrum of weedcontrol, saves time and application cost and herbicide impact on environment etc. (Green, 1987). Therefore, a need remains to evaluate new herbicides with different modes of action to tackle the ever increasing problem of complex weed flora. Keeping this in view, the present investigation was carried out to evaluate the efficacy of Pinoxaden alone and in combination with Metsulfuron and Carfentrazone against complex weed flora in barley.

\section{Materials and Methods}

An experiment to evaluate efficacy of Pinoxaden alone and in combination with Metsulfuron and Carfentrazone against complex weed flora in barley was conducted during Rabi season of 2013-14 at Wheat and Barley research farm area of Chaudhary 
Charan Singh Haryana Agricultural University, Hisar (India) located in IndoGangetic plains of North-West India with latitude of $29^{\circ} 10^{\prime}$ North and longitude of $75^{\circ} 46^{\prime}$ East at 215.2 meters above mean sea level. The experimental soil was sandy loam with $61 \%$ sand, $22.1 \%$ silt and $19.1 \%$ clay, slightly alkaline in $\mathrm{pH}$ (7.9), low in organic carbon, poor in available nitrogen and medium in available phosphorus and available potassium. Barley variety 'BH 902' was sown manually with hand plough on November 18 , 2013 by using seed rate of $100 \mathrm{~kg} / \mathrm{ha}$. The experiment was laid out in randomized block design and was replicated thrice with eleven treatments comprised of individual application of Pinoxaden@ @ 30, 40 and $50 \mathrm{~g}$ $\mathrm{ha}^{-1}$, tank mixture of Pinoxaden @ $40 \mathrm{~g} \mathrm{ha}^{-1}$ with Metsulfosulfuron @ $4 \mathrm{~g} \mathrm{ha}^{-1}$ and Carfentrazone $20 \mathrm{~g} \mathrm{ha}^{-1}$, Pinoxaden $\mathrm{fb}$ Metsulfuron $\left(40+4 \mathrm{~g} \mathrm{ha}{ }^{-1}\right), \quad$ individual application of Isoproturon@ $1000 \mathrm{~g} \mathrm{ha}^{-1}$, tank mixture of Isoproturon @ $750 \mathrm{~g} \mathrm{ha}^{-1}$ with 2,4D @ $500 \mathrm{~g} \mathrm{ha}^{-1}$ and Metsulfuron@ $4 \mathrm{~g} \mathrm{ha}^{-1}$, weedy check and weed free. Full dose of $\mathrm{P}_{2} \mathrm{O}_{5}$ (30 kg/ha), $\mathrm{K}_{2} \mathrm{O}(15 \mathrm{~kg} / \mathrm{ha})$ and half dose of nitrogen $(30 \mathrm{~kg} / \mathrm{ha})$ was applied basal at the time of sowing $(30 \mathrm{~kg} / \mathrm{ha})$. The remaining half dose of nitrogen was applied at first irrigation. The crop was raised with all other recommended package and practices.

All herbicides alone and in combination were applied as post emergence between 30-35 DAS as per treatment with knapsack power sprayer using flat fan nozzle. Observations for weed population and their dry matter accumulation were recorded at 60 and 90 DAS with the help of random quadrate $(0.5 \mathrm{x}$ $0.5 \mathrm{~m}$ ) at four places in a plot and then converted into per $\mathrm{m}^{2}$. This data was subjected to square root $(\sqrt{x+1})$ transformation to normalize their distribution before analysis. Crop was harvested on April 12, 2014. Barley grain yield and yield attributes were recorded at harvest which was statistically analyzed using analysis of variance. The weed control efficiency was worked out on the basis of weed dry matter production (Mallikarjun et al., 2014). Weed index was calculated by using the formula suggested by Gill and Vijaya Kumar (1966).

$\operatorname{WCE}(\%)=\left(\frac{\text { DMC-DMT }}{\text { DMC }}\right) \times 100$

Where,

$\mathrm{WCE}=$ weed control efficiency $(\%)$

$\mathrm{DMC}=$ dry matter of weeds in unweeded plot $\left(\mathrm{gm}^{-2}\right)$

DMT $=$ dry matter of weeds in treated plot $\left(\mathrm{gm}^{-2}\right)$

Weed index $(\%)=\left(\frac{\mathrm{N}-\mathrm{Y}}{\mathrm{X}}\right) \times 100$

Where,

$X=$ Grain yield of weed free plot

$\mathrm{Y}=$ Grain yield from treated plot

\section{Results and Discussion}

\section{Effects on weed}

\section{Weed flora}

The major weed species observed in the experimental field were Avena ludoviciana, Phalaris minor, Chenopodium album, Rumex dentatus, Euphorbia heliscopia, Anagallis arvensis, Convolvulus arvensis, Melilotus indica, Cirsium arvense, Lathyrus aphaca and Vicia sativa.

\section{Weed density}

The weeds densities were remarkably influenced by weed control treatments at 60 and 90 days after sowing (Table 1). The minimum grassy as well as broadleaf weed density was recorded under weed free treatment at 60 and 90 DAS. Among herbicides treatment, minimum grassy weed count was recorded in Pinoxaden @ $50 \mathrm{~g} \mathrm{ha}^{-1}$ at 60 and 90 DAS, which was at par with Pinoxaden @ $40 \mathrm{~g} \mathrm{ha}{ }^{-1}$, Pinoxaden+ Metsulfuron (40+4 $\left.\mathrm{g} \mathrm{ha}^{-1}\right)$, Pinoxaden $f b$ Metsulfuron (40+4 $\mathrm{g} \mathrm{ha}^{-1}$ ) and Pinoxaden+ 
Carfentrazone $\quad\left(40+20 \quad \mathrm{~g} \quad \mathrm{ha}^{-1}\right), \quad$ but significantly lower to Isoproturon+2,4-D $\left(750+500 \mathrm{gha}^{-1}\right), \quad$ Isoproturon+Metsulfuron $\left(750+4 \mathrm{~g} \mathrm{ha}^{-1}\right)$ and weedy check. Maximum grassy weed population was found in weedy check plot at 60 and 90 DAS, which was significantly higher than all other treatments. Minimum broadleaf weed count was establish in herbicide combination of Isoproturon + Metsulfuron $\quad\left(750+4 \quad \mathrm{~g} \quad \mathrm{ha}^{-1}\right)$, Pinoxaden+Carfentrazone $\left(40+20 \mathrm{~g} \mathrm{ha}^{-1}\right)$, Pinoxaden+Metsulfuron $\left(40+4 \mathrm{~g} \mathrm{ha}^{-1}\right)$ and at par with Pinoxaden $f b$ Metsulfuron $(40+4 \mathrm{~g}$ $\left.\mathrm{ha}^{-1}\right)$, Isoproturon+2,4-D $\left(750+500 \mathrm{~g} \mathrm{ha}^{-1}\right)$, but significantly lower than individual application of herbicides and weedy check at 60 and 90 DAS. Pinoxaden 40-60 $\mathrm{g} \mathrm{ha}^{-1}$ is very effective against grassy weeds without any phytotoxicity, but is ineffective against broad-leaf weeds (Singh and Punia, 2007; Chhokar et al., 2008). Since grass killers don't control the broad-leaved weeds. The tank mix application of Pinoxaden with broad-leaved herbicides (Metsulfuron and Carfentrazone) proved significantly effective in reducing mixed weed flora of barley. Carfentrazone-ethyl and Metsulfuron-methyl are additional tools for control of broadleaved weeds in barley reported by Bhullar et al., 2013. Chhokar et al., 2008 at DWR Karnal also reported that application of Pinoxaden @ $30 \mathrm{~g} \mathrm{ha}^{-1}$ effectively controlled isoproturon resistant $P$. minor in barley. Pinoxaden is very effective against grassy weeds without any phytotoxic effect, but is ineffective against broad-leaf weeds. So tank mix application of Pinoxaden with broad-leaved herbicides proved significantly effective in reducing mixed weed flora of barley. Similar findings have been observed by Singh and Punia (2007), Shoeran et al., (2013), Katara et al., (2012) and Khippal et al., (2016).

\section{Weed dry weight}

The weeds dry weight was significantly influenced by weed control treatments at 60 and 90 days after sowing (Table 1). Due to less grassy weed population in all the weed control treatments resulted in significantly lower dry weight than weedy check plot. Pinoxaden @ 50 g ha ${ }^{-1}$ resulted in significantly lowest grassy weed biomass than weedy check, individual application of Isoproturon @ $1000 \quad \mathrm{~g} \mathrm{ha}^{-1}$, Isoproturon+Metsulfuron (750+4 $\mathrm{g} \mathrm{ha}^{-1}$ ) and was comparable to Pinoxaden @ $40 \mathrm{~g} \mathrm{ha}^{-1}$, Pinoxaden+Metsulfuron $\quad\left(40+4 \mathrm{~g} \mathrm{ha} \mathrm{ha}^{-1}\right)$, Pinoxaden $f b$ Metsulfuron $\left(40+4 \mathrm{~g} \mathrm{ha}^{-1}\right)$ and Pinoxaden+Carfentrazone $\left(40+20 \mathrm{~g} \mathrm{ha}^{-1}\right)$ at 60 and 90 DAS. Maximum grassy dry weight was recorded in weedy check plot at 60 and 90 DAS, which was significantly higher than all other treatments. Minimum broadleaf dry weight was recorded in herbicide combination of Pinoxaden+Carfentrazone $\left(40+20 \mathrm{~g} \mathrm{ha}^{-1}\right)$, which was at par with Pinoxaden+Metsulfuron $\quad\left(40+4 \quad \mathrm{~g} \quad \mathrm{ha}^{-1}\right)$, Pinoxaden $f b$ Metsulfuron $\left(40+4 \mathrm{~g} \mathrm{ha}^{-1}\right)$, Isoproturon+2,4-D $\left(750+500 \mathrm{~g} \mathrm{ha}^{-1}\right)$ and Isoproturon+Metsulfuron $\left(750+4 \mathrm{~g} \mathrm{ha}^{-1}\right)$ but significantly lower than individual application of herbicides and weedy check at 60 and 90 DAS. Pinoxaden@ $90 \mathrm{~g} \mathrm{ha}^{-1}$ was superior treatment and very effective against grassy weeds but not control broadleaf weeds, because Pinoxaden is a grass killer. Pinoxaden@40 g ha ${ }^{-1}$ tank mix with broadleaved herbicides (Metsulfuron @ $4 \mathrm{~g} \mathrm{ha}^{-1}$ and Carfentrazone @ $20 \mathrm{~g} \mathrm{ha}^{-1}$ ) proved significantly effective in reducing dry weight of weeds. Sole applications of herbicides were least effective in reducing the dry weight of mixed weed flora of barley. So, tank mix application of Pinoxaden with Metsulfuron and Carfentrazone proved effective in reducing dry weight of mixed weed flora in barley. Similar findings were also reported by Khippal et al., (2016).

\section{Weed control efficiency $(\%)$}

The efficacy of herbicides estimated on the basis of weed biomass indicated that highest 
efficiency was recorded in weed free plot $(100 \%)$ at 60 and 90 DAS (Table 1). Among the herbicidal treatments, application of tank mixture Pinoxaden+Carfentrazone $(40+20 \mathrm{~g}$ $\mathrm{ha}^{-1}$ ) recorded highest weed control efficiency of $93.4 \%$ and $92.9 \%$ followed by the Pinoxaden+Metsulfuron $\left(40+4 \mathrm{~g} \mathrm{ha}^{-1}\right)(88.9 \%$ and $91.7 \%$ ) at 60 and 90 DAS, respectively. It might be due to effective weed control as reflected in associated weed density and dry weight. Minimum weed control efficiency was recorded when herbicides was applied alone. Weed control efficiency were more when Pinoxaden was tank mixed with Metsulfuron or carfentrazone or 2,4-D as compared to alone application. It indicated that tank mixture of herbicides provided better weed control efficiency than alone application of herbicide. Khippal et al., (2016) also recorded higher weed-control efficiency with Pinoxaden $f b$ Metsufuron $\left(40+4 \mathrm{~g} \mathrm{ha}^{-1}\right)$ and tank-mix application of Pinoxaden@40 $\mathrm{g} \mathrm{ha}^{-1}$ with Metsulfuron @ 4 $\mathrm{g} \mathrm{ha}^{-1}$ and Carfentrazone @ $20 \mathrm{~g} \mathrm{ha}^{-1}$ over their alone application of herbicide.

\section{Effect on crop}

\section{Effective tillers $\mathbf{m}^{-2}$}

Maximum numbers of effective tillers were recorded in weed free treatment, which was statistically at par with all other treatments except weedy check (Table 2). Among the herbicidal treatments maximum number of effective tillers were recorded in Pinoxaden+Carfentrazone $\left(40+20 \quad \mathrm{~g} \mathrm{ha}^{-1}\right)$ followed by Pinoxaden $f b$ Metsulfuron $(40+4$ $\left.\mathrm{g} \mathrm{ha}^{-1}\right)$ and Isoproturon+2,4-D (750+500 $\mathrm{g}$ ha $\left.{ }^{1}\right)$. Significantly lower number of productive tillers was recorded in weedy check than other weed control treatments due to more weed density and dry weight (Table 2).

\section{Grains earhead $^{-1}$}

Number of grains earhead ${ }^{-1}$ is another important component of yield (Table 2). Significantly higher number of grains earhead $^{-1}$ was recorded in weed free plot than weedy check and alone applications of herbicides, but statistically at par with all combined application of herbicides. Minimum grains earhead $^{-1}$ was recorded in weedy check plot due to more crop-weed competition for source of nutrients, light and water.

\section{0-grain weight}

The analysis of the data showed that the different treatments affected 1000-grain weight significantly (Table 2). Boldest seed was obtained with Pinoxaden $f b$ Metsulfuron $\left(40+4 \mathrm{~g} \mathrm{ha}^{-1}\right)$, which was significantly higher than individual application of herbicides and weedy check, but at par with tank mixed application of Pinoxaden @ $40 \mathrm{~g} \mathrm{ha}^{-1}$ with Metsulfuron@4 g ha ${ }^{-1}$ and Carfentrazone @ $20 \mathrm{~g} \mathrm{ha}^{-1}$. These results are corroborated with the results of Khippal et al., (2016), who concluded that maximum 1000-grain weight was recorded in those plots which were treated with the mixture of herbicides while minimum 1000-grain weight was recorded in weedy check plots.

\section{Grain yield (q ha $\left.{ }^{-1}\right)$}

Different herbicides treatments had a significant effect on the grain yield (Table 2). Perusal of the data exhibited that the maximum grain yield was recorded in weed free $\left(55.4 \mathrm{q} \mathrm{ha}^{-1}\right)$, which was very near about to application of Pinoxaden $f b$ Metsulfuron @ 40+4 $\mathrm{g} \mathrm{ha}^{-1}$ (54.4 q ha $\mathrm{q}^{-1}$. Among the herbicide treatment, Pinoxaden $f b$ Metsulfuron @ 40+4 g ha ${ }^{-1}$ produced significantly higher grain yield than alone application of different herbicide and weedy check but statistically at par with other tank mixture of Pinoxaden @ $40 \mathrm{~g} \mathrm{ha}^{-1}$ with Metsulfuron@4 g ha ${ }^{-1}$ and Carfentrazone @ $20 \mathrm{~g} \mathrm{ha}^{-1}$. 
Table.1 Effect of herbicide treatments on weed density, weed dry weight, weed control efficiency (60 and 90 DAS) and weed index (\%) of barley

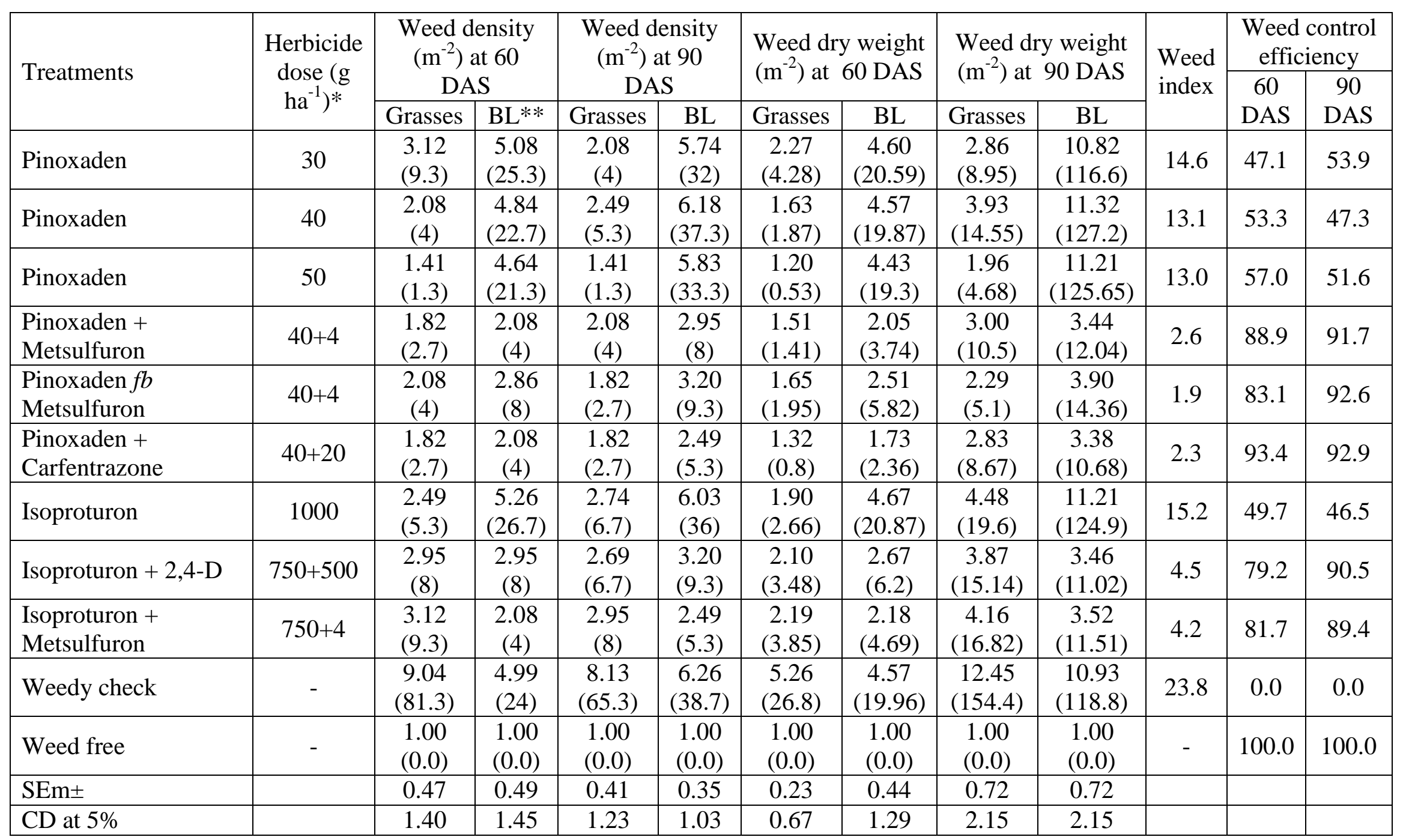

*Spray of herbicides at 30-35 days after sowing (DAS), ** BL - broad leaf weeds,

Original values given in parenthesis were square root transformed for statistical analysis. 
Table.2 Effect of different herbicide treatments on yield and yield attributes of barley

\begin{tabular}{|c|c|c|c|c|c|c|c|}
\hline Treatments & $\begin{array}{c}\text { Herbicide } \\
\text { dose }\left(\mathrm{g} \mathrm{ha}^{-1}\right)\end{array}$ & $\begin{array}{l}\text { Effective } \\
\text { tillers } \mathbf{m}^{-2}\end{array}$ & $\begin{array}{c}\text { Grains } \\
\text { earhead }^{-1}\end{array}$ & $\begin{array}{l}1000 \text { Grain } \\
\text { weight }\end{array}$ & $\begin{array}{l}\text { Grain yield } \\
\qquad\left(\mathbf{q} \mathbf{h a}^{-1}\right)\end{array}$ & $\begin{array}{c}\text { Biomass } \\
\left(\mathbf{q} \mathbf{h a}^{-1}\right)\end{array}$ & $\begin{array}{c}\text { Harvest } \\
\text { index } \\
(\%) \\
\end{array}$ \\
\hline Pinoxaden & 30 & 392 & 46.03 & 39.95 & 47.3 & 141.8 & 33.4 \\
\hline Pinoxaden & 40 & 389 & 46.30 & 40.36 & 48.2 & 143.1 & 33.6 \\
\hline Pinoxaden & 50 & 387 & 46.11 & 40.42 & 48.0 & 142.8 & 33.6 \\
\hline Pinoxaden + Metsulfuron & $40+4$ & 402 & 47.97 & 42.05 & 53.9 & 158.4 & 34.2 \\
\hline Pinoxaden $f b$ Metsulfuron & $40+4$ & 405 & 48.43 & 41.96 & 54.4 & 160.5 & 33.9 \\
\hline Pinoxaden + Carfentrazone & $40+20$ & 409 & 48.77 & 42.84 & 54.1 & 157.2 & 34.4 \\
\hline Isoproturon & 1000 & 390 & 46.13 & 39.54 & 46.9 & 142.5 & 32.9 \\
\hline Isoproturon+2,4-D & $750+500$ & 405 & 47.88 & 42.05 & 52.8 & 157.1 & 33.7 \\
\hline Isoproturon + Metsulfuron & $750+4$ & 400 & 48.82 & 41.98 & 53.0 & 156.6 & 33.9 \\
\hline Weedy check & - & 360 & 44.25 & 38.83 & 42.1 & 128.0 & 32.9 \\
\hline Weed free & - & 413 & 48.97 & 42.76 & 55.4 & 161.7 & 34.3 \\
\hline SEm \pm & & 8.57 & 0.86 & 0.72 & 1.52 & 4.38 & 0.71 \\
\hline $\mathrm{CD}$ at $5 \%$ & & 25.47 & 2.55 & 2.14 & 4.52 & 13.0 & $\mathrm{NS}$ \\
\hline
\end{tabular}


Minimum grain yield was recorded in weedy check plots $\left(42.1 \mathrm{q} \quad \mathrm{ha}^{-1}\right)$, which was significantly inferior to all herbicidal treatments. Presence of weeds throughout the growing season brought about $24 \%$ reductions in grain yield as compared to weed free. The increase in grain yield of barley due to application of Pinoxaden @ $40 \mathrm{~g} \mathrm{ha}^{-1} \mathrm{fb}$ Metsulfuron@ @ $\mathrm{g} \mathrm{ha}^{-1}$ was $22.5 \%$ over weedy check. Similar findings were also reported by Sheoran et al., (2013), who concluded that herbicide application and hand weeding increased grain yield of wheat as compared to weedy check. Khippal et al., (2016) also observed that highest grain yield was recorded when Pinoxaden @ $40 \mathrm{~g} \mathrm{ha}^{-1} \mathrm{fb}$ Metsulfuron @ $4 \mathrm{~g} \mathrm{ha}^{-1}$ was applied. Increased grain yield in herbicide mixture could be ascribed to poor weed growth, weed dry matter and more number of grains spike ${ }^{-1}$ and test weight as compared with alone application of herbicides and untreated treatment. Enhanced grain yield in herbicide treated plots might be due to availability of more nutrients, light, moisture and space to the crop resulting in better crop growth (Mahmood et al., 2013). The grain yield was negatively associated with total weed density, weeds biomass and positively associated with number of tillers $\mathrm{m}^{-2}$, grains earhead ${ }^{-1}$ and test weight. Therefore, weeds in weedy check reduced the grain yield of barley. More yields in herbicide treated plot might be due to effective control of weeds, less crop weed competition throughout the crop growth period which resulted in improved growth parameters of the crop (Singh et al., 2015).

\section{Biological yield $\left(\mathrm{q} \mathrm{ha}^{-1}\right)$}

Different herbicidal treatments had a significant effect on the biological yield (Table 2). Maximum biological yield was recorded in weed free $\left(161.7 \mathrm{q} \mathrm{ha}^{-1}\right)$ plot. Among the herbicides treatments highest biological yield was found in Pinoxaden $f b$
Metsulfuron $\left(40+4 \quad \mathrm{~g} \quad \mathrm{ha}^{-1}\right)$, which was statistically at par with the combined application of Pinoxadan@ @ $40 \mathrm{~g} \mathrm{ha}^{-1}$ with Metsulfuron@4 $\mathrm{g} \mathrm{ha}^{-1}$ and carfentrazone @ $20 \mathrm{~g} \mathrm{ha}^{-1}$, Isoproturon+Metsulfuron $(750+4 \mathrm{~g}$ $\mathrm{ha}^{-1}$ ), but significantly higher than alone application of herbicides and weedy check. Whereas, minimum biological yield was recorded in weedy check (128.0 q ha $\left.{ }^{-1}\right)$. Increased biological yield in all herbicidal treatment was due to poor weed growth, weed dry matter and more number of effective tillers, grains spike $^{-1}$ and test weight as compared to weedy check. Presence of weeds throughout the growing season brought about $20.8 \%$ reductions in biological yield as compared to weed free. Increase in biological yield in weed free plot was might be due control of weeds, which interferes resource utilisation (nutrients, light, water and space) with crop plants. Enhanced biological yield in herbicide treated plots might be due to availability of more nutrients, light, moisture and space to the crop plants resulting in better crop growth (Mahmood et al., 2013).

\section{Harvest index (\%)}

Harvest index was not affected significantly by different weed control treatments (Table 2). Tank mixed application of Pinoxaden @ $40 \mathrm{~g} \mathrm{ha}^{-1}$ with Carfentrazone @ $20 \mathrm{~g} \mathrm{ha}^{-1}$ found numerically higher harvest index $(34.4 \%)$ indicate its better assimilate partitioning efficiency (source sink). Minimum harvest index was recorded in weedy check $(32.9 \%)$ and individual application of Isoproturon @ $1000 \mathrm{~g} \mathrm{ha}^{-1}$. The numerically increase in harvest index with weed control practices may be attributed to suppression of weed growth resulting in more availability of plant nutrients, soil moisture and space to crop, which favored utilization of photosynthates for better grain yield formation (Amare et al., 2016). 


\section{Weed index $(\%)$}

Weed index indicate the reduction of grain yield (Table 1). Weed index was minimum under Pinoxaden@ $90 \mathrm{~g} \mathrm{ha}^{-1} \mathrm{fb}$ Metsulfuron @ $4 \mathrm{~g} \mathrm{ha}^{-1}(1.9 \%)$, followed by Pinoxaden @ $40 \mathrm{~g} \mathrm{ha}^{-1}+$ Carfentrazone @ $20 \mathrm{~g} \mathrm{ha}^{-1}$ $(1.58 \%)$ and maximum under weedy check (23.8\%). Higher weed control efficiency with lower weed index under Pinoxaden $f b$ Metsulfuron $\left(40+4 \mathrm{~g} \mathrm{ha}^{-1}\right)$ applied plots were due to effective weed control as evident from lower weed population and dry weight than other treatments.

Experiment concludes that Pinoxaden @ $50 \mathrm{~g}$ $\mathrm{ha}^{-1}$ was very efficient against grassy weeds. Tank mix application of Pinoxaden @ $40 \mathrm{~g}$ ha $^{-1}$ with broad-leaved herbicides i.e. Metsulfuron@ $9 \mathrm{~g} \mathrm{ha}^{-1}$ and Carfentrazone @ $20 \mathrm{~g} \mathrm{ha}^{-1}$ and Pinoxaden $f b$ Metsulfuron (40+4 $\mathrm{g} \mathrm{ha}{ }^{-1}$ ) proved significantly in controlling mixed weed flora. Pinoxaden $f b$ Metsulfuron @ $40+4 \mathrm{~g} \mathrm{ha}^{-1}$ produced significantly higher grain yield than individual application of different herbicides and weedy check but statistically at par with other tank mixture of Pinoxaden@40 g ha ${ }^{-1}$ with Metsulfuron@4 $\mathrm{g} \mathrm{ha}^{-1}$ and Carfentrazone @ $20 \mathrm{~g} \mathrm{ha}^{-1}$. Presence of weeds throughout the growing season brought about $24 \%$ reductions in grain yield as compared to weed free treatment. Higher weed control efficiency with lower weed index was recorded under Pinoxaden $f b$ Metsulfuron $\left(40+4 \mathrm{~g} \mathrm{ha}^{-1}\right)$.

\section{References}

Amare, T., Raghavaiah, C.V. and Zeki, T. 2016. Productivity, yield attributes and weed control in wheat (Triticum aestivum L.) as influenced by integrated weed management in Central High Lands of Ethiopia, East Africa. Adv. Crop Sci. Technol., 4(1): 1-4.

Balyan, R.S., Malik, R.K. and Panwar, R.S.
1993. Efficacy of diclofop-methyl applied alone and in combination with other herbicides for weed control in wheat. Haryana Agri. Univ. J. Res., 23: 160-164.

Bhullar, M.S., Simerjit Kaur, Tarundeep Kaur, Singh, T., Singh, M. and Jhala, A.J. 2013. Control of broadleaf weeds with post-emergence herbicides in four barley (Hordeum spp.) cultivars. Crop Protection, 43: 216-222.

Chhokar, R.S., Sharma, R.K. and Verma, R.P.S. 2008. Pinoxaden for controlling grass weeds in wheat and barley. Indian J. Weed Sci., 40: 41-46.

Chhokar, R.S. and R.K. Malik. 2002. Isoproturon resistant Phalaris minor and its response to alternate herbicides. Weed Technol., 16: 116-123.

Gill, G.S. and Vijaya Kumar. 1966. Weed index - A new method for reporting weed control trials. Indian J. Agron., 4(1): 96-98.

Green, J.M. 1987. Herbicide antagonism at the whole plant level. Weed Technol., 3: 316-317.

Hoffer, U., Muehlebach, M., Hole, S. and Zoschke, A. 2006. Pinoxaden - for broad spectrum grass weed management in cereal crops. J. Plant Dis. Protection, 20(5): 989-995.

Katara, P., Kumar, S., Rana, S.S. and Chander, N. 2012. Combination of Pinoxaden with other herbicides against complex weed flora in wheat. Indian J. Weed Sci., 44(4): 225-230.

Khippal, A., Kharub, A., Kumar, D., Verma., A., Kumari, S. and Kumar, Y. 2016. Pinoxaden in combination with other herbicides against complex weed flora in barley. Int. J. Trop. Agri., 34(3): 805809.

King, S.R. 2007. Effect of mesosulfuron rate and formulation on wild oat (Avena fatua) control and malt barley tolerance. Weed Technol., 21: 771-776. 
Kumar, S., Angiras, N.N. and Rana, S.S. 2011. Bio-efficacy of clodinafoppropargly + Metsulfuron-methyl against complex weed florain wheat. Indian $J$. Weed Sci., 43: 195-198.

Mahmood, A., Iqbal, J., Chattha, M.B. and Azhar, G.S. 2013. Evaluation of various herbicides for controlling grassy weeds in wheat. Mycopath., 11(1): 39-44.

Mallikarjun, Channabasavanna, A.S., Saunshi, S. and Shrinivas, C.S. 2014. Effect of herbicides on weed control and yield of wet seeded rice (Oryza sativa L.). The Bioscan, 9(2): 581-583.

Pal, D., Kumar, S. and Verma, R.P.S. 2012. Pusa Losar (BHS 380) - the first dualpurpose barley variety for northern hills of India. Indian J. Agri. Sci., 82: 164165.

Ram, H. and Singh, A. 2009. Studies on efficacy of tank mix herbicides for the control of weeds in irrigated barley (Hordeum vulgare L.). Indian J. Weed Sci., 41: 167-171.

Shoeran, S., Punia, S.S., Yadav, A. and Singh, S. 2013. Bioefficacy of Pinoxaden in combination with other herbicides against complex weed flora in wheat. Indian J. Weed Sci., 45(2): 90-92.

Singh, R., Singh, A.P., Chaturvedi, S., Pal, R.R. and Jodh Pal. 2015. Control of complex weed flora in wheat by metribuzin + clodinafop application. Indian J. Weed Sci., 47(1): 21-24.

Singh, S. and Punia, S.S. 2007. Sensitivity of barley (Hordeum vulgare) to herbicides of different modes of action. Indian $J$. Weed Sci., 39(3\&4): 205-210.

Singh, S. 2007. Role of management practices on control of isoproturon-resistant littleseed canary grass (Phalaris minor) in India. Weed Technol., 21: 339-346.

Suresha, K., Ashish, R.S.S., Negi, S.C. and Kumar S. 2015. Assessment of yield and nutrient losses due to weeds in maize based cropping systems. Himachal J. Agri. Res., 41(1): 42-48.

Yaduraju, N.T. 2006. Herbicide resistant crops in weed management. In: The Extended Summaries, Golden Jubilee National Symposium on Conservation Agriculture and Environment. October, 26-28, Banaras Hindu University, Banaras, pp 297-98.

\section{How to cite this article:}

Bhagat Singh, Mukesh Kumar, A.K. Dhaka and Lamba, R.A.S. 2017. Efficacy of Pinoxaden alone and in Combination with Metsulfuron-methyl and Carfentrazone-ethyl against Complex Weed Flora in Barley (Hordeum vulgare L.). Int.J.Curr.Microbiol.App.Sci. 6(4): 134-143. doi: https://doi.org/10.20546/ijcmas.2017.604.016 